\title{
Consumption Behavior of Algerians During the Period of the Covid-19 Pandemic Crisis
}

Kamel Chikhi

Higher School of Management - Tlemcen (Algeria)

Follow this and additional works at: https://digitalcommons.uri.edu/mgdr

Part of the Anthropology Commons, Development Studies Commons, Economics Commons, Environmental Studies Commons, Marketing Commons, Other Business Commons, Public Health Commons, and the Sociology Commons

\section{Recommended Citation}

Chikhi, Kamel (2020) "Consumption Behavior of Algerians During the Period of the Covid-19 Pandemic Crisis," Markets, Globalization \& Development Review. Vol. 5: No. 4, Article 4.

DOI: 10.23860/MGDR-2020-05-04-04

Available at: https://digitalcommons.uri.edu/mgdr/vol5/iss4/4

This Dialogue is brought to you for free and open access by DigitalCommons@URI. It has been accepted for inclusion in Markets, Globalization \& Development Review by an authorized editor of DigitalCommons@URI. For more information, please contact digitalcommons-group@uri.edu. 

Crisis

\section{Markets, Globalization \& Development Review}
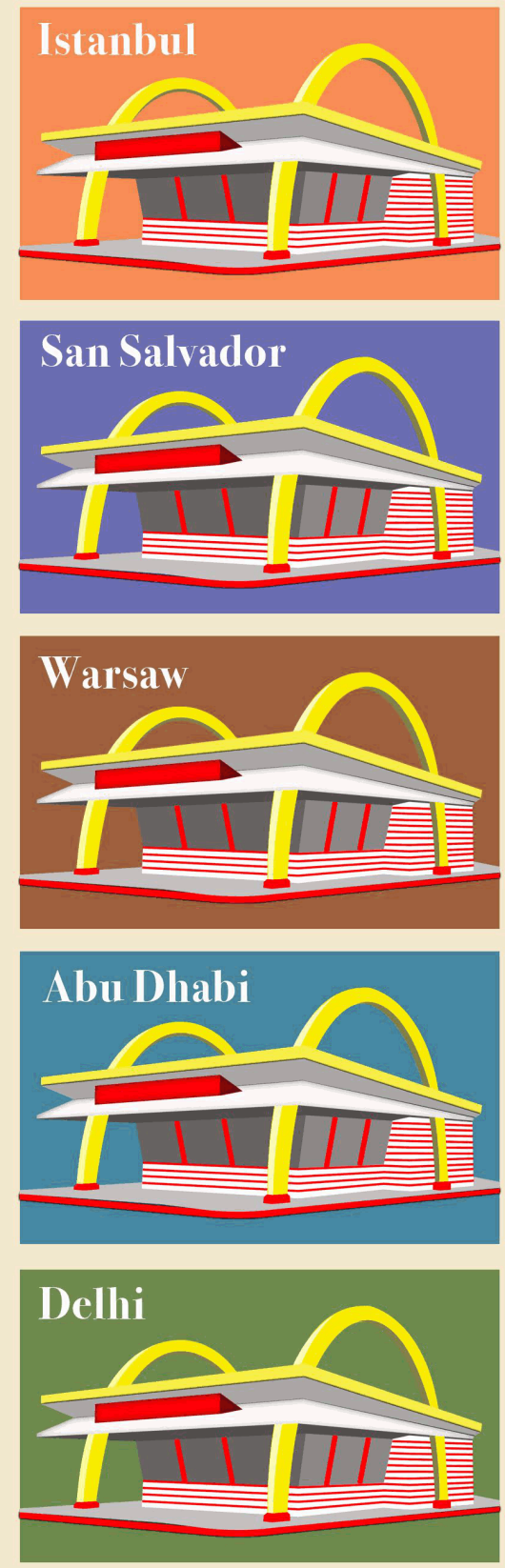
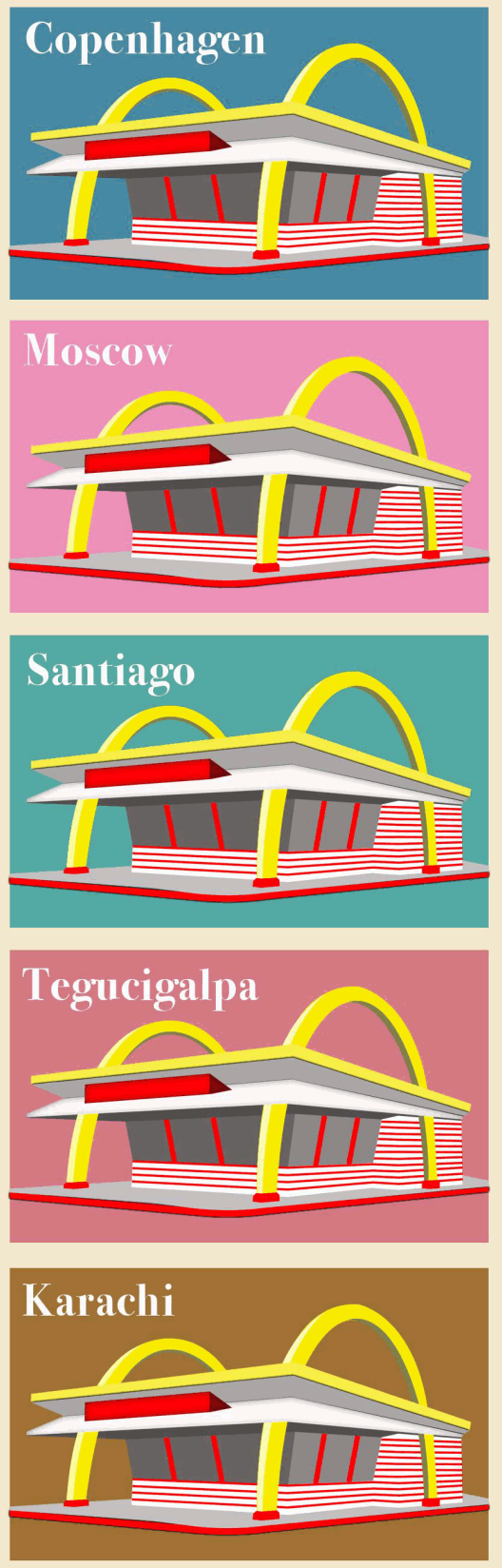
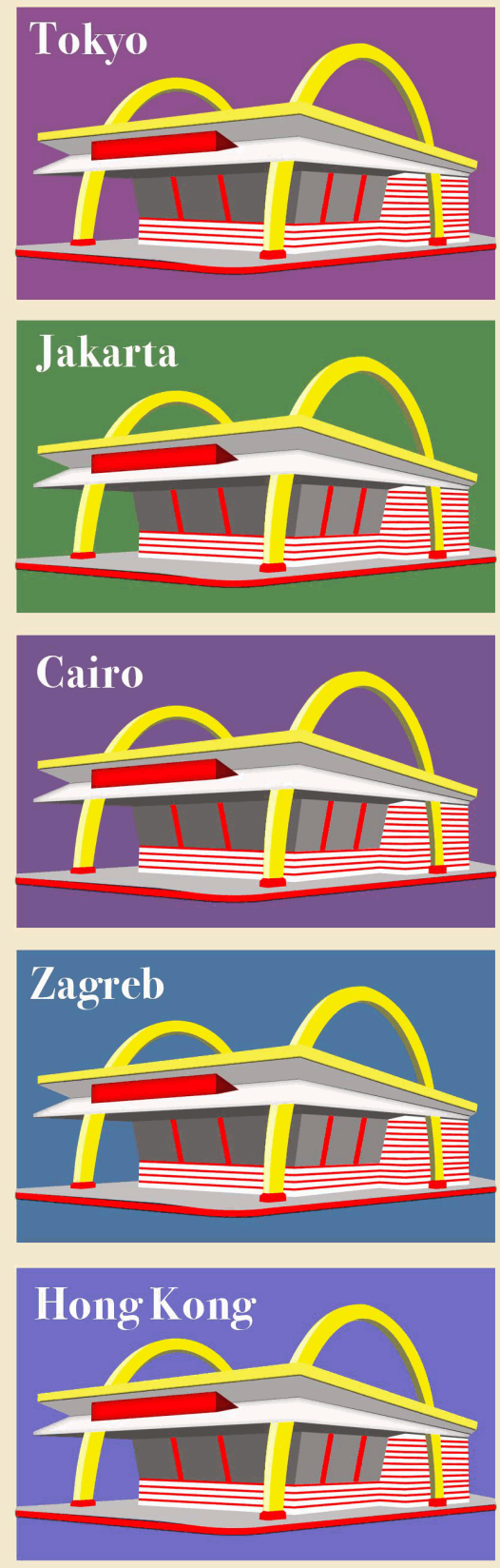

This dialogue is available in Markets, Globalization \& Development Review: https://digitalcommons.uri.edu/mgdr/ vol5/iss $4 / 4$ 


\section{Consumption Behavior of Algerians During the Period of the Covid-19 Pandemic Crisis}

\section{Introduction}

The Covid-19 health crisis has caused a decline in the world economy, particularly in Algeria (Mebtoul 2020). Between May and early July 2020, the World Bank anticipated a recession in Algeria in 2020, leading to a $6.4 \%$ shrinkage of the economy. The IMF estimated a shrinkage of more than $5 \%$ and the African Development Bank (ADB) of more than 4\%. According to NSO (National Statistics Office) data published on July 25, 2020, in the 1st quarter of 2020, the Algerian economy recorded negative growth of $-3.9 \%$, against positive growth (+ $1.3 \%$ ) in the same period of 2019.

The pandemic's most remarkable social consequences are certainly the increase in the unemployment rate, following the sudden closure of several economic enterprises and several businesses, and the reduction in income for certain sectors. Such a development has significantly affected the consumption behaviors of individuals. Apart from the civil service which continued to provide minimum service, only the food and pharmaceutical sectors continued to operate.

Indeed, the state of emergency announced by the World Health Organization (WHO) prompted countries to take strong measures to face the pandemic, in order to ensure good healthcare and the availability of drugs to patients. Likewise, the Food and Agriculture Organization (FAO) of the United Nations recommended that countries do their best to ensure the continuity of trade and food supply chains, including increasing agricultural production during this international health crisis. It identified 135 million people around the world who were facing food insecurity.

Experts believe that a splitting of socioeconomic categories has revealed two segments of consumers and citizens: those in the civil service sector and socio-professional enterprises whose incomes have not been affected and those in the free economic sector and the selfemployed - in industries such as building, tourism, transport, etc. whose incomes have been affected severely due to the containment and restrictions imposed by the pandemic.

This Dialogue contribution attempts to understand the behavioral changes of Algerian consumers during the health crisis: before, during and post-crisis. It follows other MGDR contributions dealing with impacts of the pandemic on consumers, consumption and markets (see e.g., Cambefort 2020; Mizukoshi and Hidaka 2020). A review of 
the literature allows us to highlight the main behavioral characteristics of consumption, with a focus on Algeria, during the pandemic crises.

\section{Some Relevant Literature: A Brief Review}

In general, the phenomenon of consumption is explained as resulting from a combination of utility, distinction and the pursuit of pleasure and satisfaction (Langlois 2002). The impacts of the pandemic in Algeria are complex and were spelled out by Mohamed Cherif Belmihoub, Minister Delegate to the Prime Minister in charge of foresight, on Radio Alger Channel 3 on August 17, 2020, as "the cumulative or superimposed crises (economic, social and health) and particularly the crisis of 2014 (sudden fall in the prices of hydrocarbons), the fall in the prices of hydrocarbons this year 2020 to which is added the crisis of the Covid-19 which totally disrupted our economic system" (Belmihoub 2020). Numerous studies have shown that each crisis affects consumers not just economically, but also psychologically as well, mainly at the start (Cambefort 2020; Köksal and Özgül 2007). People start to worry about their future and no longer like shopping in established and habitual ways (Ang, Leong and Kotler 2000).

During crises, consumers do not want to spend money on high quality products, even if they could afford it (Ferrell and Hartline 2002). In addition, the studies by Ang, Leong and Kotler (2000) and Köksal and Özgül (2007) found that most of the time, consumers are more likely to think in monetary terms during the financial crisis. They buy only what is needed, switch to cheaper brands, and have more rational views toward strongly promoted products.

According to the literature, consumers could be led to modify their purchasing behavior, but with questionable results in the face of an economic crisis. According to Solomon (1996), consumer behavior is extremely complex, starting with the choice of the product, its consumption until its liquidation (or its elimination or disposal). Some market observers even evoke the "dizziness of the consumer" who must do a ceaseless job of processing information. Deaton (1992) advances the idea of "buffer savings" or precautionary savings. For Deaton, in times of crisis, people reduce their consumption and save money to deal with possible difficult situations. Consumption thus gets shaped by economic agents considering risks and practicing risk aversion.

Furthermore, consumer behavior is influenced by the importance that consumers place on nutrition, health, food quality characteristics, price, psychological and socio-demographic characteristics (Tsourgiannis et al. 2014). During an economic crisis, the purchasing behavior of consumers varies according to their expectations. Ang, Leong and Kotler (2000) have shown that in times of economic turbulence, consumers buy fewer products, replace luxury 
products with more economical products, and decisions are based primarily on price. Consumers buy selected products that mainly meet their basic needs.

According to Mansoor and Jalal (2011) as well as Flatters and Willmott (2009), in times of economic crisis, consumer behavior is described by a smoothing of consumption at different levels. People are not so willing to pay more for products that can be replaced with cheaper products. Consumers have redefined what they consider "necessities" and what are considered "luxury goods". These results were confirmed by the Boston Consulting Group study conducted in 2011 , which found that $73 \%$ of consumers surveyed during a crisis said they only bought absolutely necessary products. In addition, the hierarchy of consumers' values changes, with "savings", "health", "value for money" and similar concerns rising to the top (Tsourgiannis et al. 2014).

The literature on crisis consumption thus indicates that consumers change their purchasing behavior when affected by an economic crisis. Their buying intentions vary, however, depending on their cultural background and other factors. Ajzen brought to light the intention model of the theory of planned behavior (Ajzen 1985; 1991). He showed that consumers retain buying and consuming intentions, and continue to adopt planned behaviors during a crisis.

\section{Consumption of Algerians at the Beginning of the Covid- 19 Alert}

To stem the spread of the virus, governments started confining populations, causing production to drop to a scale hitherto unknown in peacetime. The period of confinement imposed thus upset the normal and established purchasing and consumption habits and practices, particularly in the time spent on food: supply methods, meal preparation, and low attendance at or total avoidance of out-of-home restaurants. These habits and practices cited are also influenced by various individual factors such as sensitivity to food waste and to environmental or domestic economy motivations (Dyen, Le Borgne and Sirieix 2020).

The Covid-19 alert generated an unusual buying rate for some product categories. The demand for food products increased by $40 \%$ according to the president of ANCA, Algeria's National Association of Traders and Craftsmen. The products that were particularly affected were semolina, canned food, sugar, oil, coffee and pulses or lentils. It was noted that in the wilayas (i.e., districts) of Algiers, Tipasa and Blida, the increase in demand among food traders reached $60 \%$ to $70 \%$ above normal levels. At the level of small shops or convenience stores, "the quantity of products that normally sold in a week to ten 
days was sold in two days". This created a "destabilization of the supply chain of these businesses as retailers generally stock on a weekly basis". In short, this period imposed a rationing of essential products on consumers, similar to what happens in times of war shortages. An appeal was launched by consumer protection associations for more rationalization in consumption.

Moreover, a list of products temporarily suspended for export until the end of the crisis was established by the Ministry of Commerce in order to continue to supply the domestic market, in accordance with the government directive number 111/PM of March-22-2020. These items - whose exports were suspended - were basic food products and hygiene and pharmaceutical items, and included semolina, flour, pulses or lentils, rice, pasta, oils, sugar, coffee, mineral water, tomato paste, prepared foods, milk in all its forms including those forms and formulas intended for children, fresh vegetables and fruits except dates, red and white meats, medical and paramedical equipment, medicines and pharmaceuticals, personal hygiene products and household detergents.

\section{Consumption Experience of Algerians During the Containment and Lockdown Phase}

Bread, being the emblematic product of Algerians, saw its purchase fall by $30 \%$. According to the National Federation of Bakers (FNB), bread production fell from 50 million baguettes per day before the start of sanitary confinement to 33 million baguettes per day during confinement, a decrease of $30 \%$. An unexpected and salutary side effect was a reduction in the usual rate of food waste. Studies carried out in other countries - United Kingdom, Greece and Tunisia - showed parallel results. These studies revealed that waste depends on many factors related to the characteristics of the products stored, the skills and practices of the members of the household, as well as lifestyle and life-stage factors. These countries also recorded a strong reduction in food waste during the confinement period.

Regarding the replacement of plastic bags by paper bags, the representative of the FNB (the bakers federation) noted that only 60 bakeries had benefited from it since its launch and called on the Ministry of Commerce to identify the reasons for stopping distribution from paper bags to bakeries and the imperative to relaunch the operation to preserve the environment and the health of citizens. At the same time, water consumption across the entire national territory increased by $10 \%$ since the start of the Covid-19 crisis according to the Ministry of Water Resources (APS 2020); because the need for hygiene (washing, sanitizing) experienced a strong increase. 
During containment, a certain category of consumers ate more, moved less and exerted less physical effort, and as a result, they gained more weight (an average estimated 4 kilograms per adult person). On the other hand, other consumers experienced restrictions. In fact, the preference for Algerian products, even if imported products were available, increased significantly. Some consumers even mobilized in associations for voluntary community-oriented acts such as cleaning and sterilization of public places. We can say that they have oriented themselves towards sustainable consumption patterns, responsible citizenship, a sense of unity, and commitment to their localities. It is interesting to note that, during the pandemic, Japanese consumers and citizens exhibited solidarity with struggling shop owners and service providers by buying more and buying local (Mizukoshi and Hidaka 2020).

In Algeria, additionally, containment led to strong growth in sales of preventive health products and basic necessities. A significant increase in retail sales was recorded in the category "medical, pharmaceutical and cosmetic products". This increase was mainly driven by masks and disinfectant solutions. The cost of protective masks weighed especially for small and medium budgets: it is estimated that for a family of 5 people, the average budget spent is 14,400 DZD (about US \$108) for disposable masks and around 1,500 DZD (about US \$11) for washable masks.

In addition, the consumption of food supplements and health foods also got boosted (Vitamin C, Zinc, Vitamin A, etc.) due to the supposed role of micronutrients in strengthening immunity to deal with this pandemic. Similarly, the purchase and consumption of traditional aromatic and medicinal plants also increased during this period.

Large retail outlets such as hypermarkets, supermarkets and shopping centers had great difficulty due to their government-imposed closures. Regular shoppers were forced to frequent small shops with full respect for barrier measures (masking, social distancing, etc.) in an effort to avoid becoming infected with the virus.

Regarding food prices, the Food and Agriculture Organization (FAO) of the United Nations announced on its website that world food prices fell slightly in July 2020 , due to the drop in the prices of cereals, dairy products and sugar, which in particular made it possible to offset the prices of meat and oils. In Algeria, the Minister of Commerce estimated that the prices of food products were reasonable if we compare them with those of foregoing year and the one before, with the exception of the prices of imported products, attributable to the significant fall in the value of the Algerian dinar. It was also observed that if there is an increase in prices, it is in relation to the increase in demand for certain foods especially those related to special occasions such as Ramadan, Eid, etc. Most of the time, it is the consumers who 
create these price disruptions, often changing their consumption pattern overnight (Marouf-Araibi 2020).

It should be noted that this period of confinement gave rise to a certain culture of innovation among consumers - especially among the most rational and informed - in the supply, cooking, storage, and management of leftovers, which made it possible to conserve and reuse food items while reducing waste.

From an environmental standpoint, this health crisis caused, in the short term, a drop in global CO2 (Carbon Dioxide) emissions of around 5 Gt - 10 times the drop observed in 2009 - thereby making 2019 the year of peak emissions (with drastic reductions in 2020). Despite the rebound effect that will inevitably appear at the end of confinement, such a decline will not be reversed entirely in the following years (De Perthuis 2020). In the longer term, the pandemic will catalyze economic and societal transformations that will give new weapons to post-Covid-19 societies to act in the face of climate risk. Depending on their content, plans to restart activity at the end of containment may accelerate or slow down these pro-sustainability structural transformations.

\section{Post-Containment Consumption Behavior}

After a forced diet of confinement (also forced stoppage of work), food consumption was rebalanced thanks in particular to gradual decontainment measures and the stabilization of the prices of main food products such as seasonal fruits and vegetables as well as white meats and fish.

Yet, there are major long-term changes under way. With the rise of environmental concerns, the consumption of animal proteins is set to decrease sharply in the years to come for reasons of cost, health, ethics and the environment. Indeed, the FAO stated in a recent report that the consumption of meat has declined in the world, a consequence, among other things, of the Covid-19 crisis.

Large sales areas are struggling to restart because two types of consumers are in oppositional modes: some consumers waiting and willing for transformational change, and other consumers - for reasons that could be economic, political, or cultural - who are unwilling or unable to change.

In Algeria, the special summer seasonal sales were not announced for most businesses - especially clothing and household appliances - due to the difficulties encountered during the pandemic and the lack of supply of new products.

According to consumer protection associations, more and more consumers have turned to online commerce, despite delays in the evolution of e-payment systems. Children's clothing, household items, bedding and more make up the bulk of products purchased on the web, 
even though delivery services (i.e., shipping and handling) cost between 200 DZD and 800 DZD, which is considered an expensive amount for most Algerian families.

As for economic recovery and savings, the question for the government is whether they will be ensured by the protection and stimulation of consumption or by the restoration of the economic health of those companies and sectors that have suffered greatly in the pandemic period. It is therefore reasonable to direct part of this savings not towards consumption but rather towards investment in companies to strengthen their equity and improve their financial soundness, which would avoid a scenario of cascading bankruptcies or a financial crisis (Moati 2020).

The impressive and rapid rise in the spread of the deadly coronavirus has caused concern and fear among citizens. This has upset the habits, practices, rites and behavior of Algerians (Kotler 2020). Confronted with - and because of - these fears, it appears that, somewhat paradoxically, many benefits have resulted from this crisis. These include the reduction in food waste, the sharp increase in orders and purchases over the Internet (an outcome long awaited by electronic platforms), the increase in the consumption of local products, and finally, the increase in domestic savings.

Perhaps, in terms of some of the other consequences of Covid19 , we are witnessing a new era characterized by a form of partial deglobalization that could offer possible opportunities for change towards a better future (Dholakia and Atik 2020a; Dholakia and Atik 2020b).

\section{Concluding Comments}

In conclusion, we can ask the following question: How can we perpetuate the sustainable practices and behaviors actualized and realized during confinement and preserve the altruistic behaviors of consumption after the Covid-19 containment has ended? Consumers are called upon today to become more involved in the construction and modernization of their national economy. The consumer must be a "consumer-entrepreneur", as Rochefort (1997) has emphasized, because the development of entrepreneurship depends on the dynamic intention of individual characteristics and socio-environmental factors (Gasse 2003).

Finally, social marketing, applied in particular by the associative movement in its social awareness campaigns, must play an important role in preventing unsustainable recurring behaviors from taking hold (Lee and Kotler 2019) and reappearing after the period of confinement has ended. We therefore need movements, such as consumer protection associations (Atik and Dholakia 2020), to keep unsustainable behaviors at bay - and to anchor sustainable, supportive behaviors deeply in our lives. 


\section{References}

Ajzen, Icek (1991), "The Theory of Planned Behavior," Organization Behavior and Human Decision Processes, 50, 179-271. https://doi.org/10.1016/0749-5978(91)90020-T

(1985), "From Intentions to Actions: A Theory of Planned Behavior," In J. Kuhi \& J. Beckmann (Eds.), Actionócontrol: From Cognition to Behavior, Heidelberg: Springer, 11-39,

Ang, Swee H., Siew M. Leong, and Philip Kotler (2000), "The Asian Apocalypse: Crisis Marketing for Consumers and Businesses," Long Range Planning, 33 (1), 97-119. https://doi/org/10.1016/S0024-6301(99)00100-4

APS, (2020), "Water Consumption in Algeria Has Increased by $10 \%$ since the Start of the Covid-19 Crisis" Published Thursday, June 04, 2020 (accessed on September 05, 2020), [available at: http://www.aps.dz/economie]

Atik, Deniz and Dholakia, Nikhilesh (2020), "The Complex Challenges of Protecting Consumers," Markets, Globalization \& Development Review, 5 (2), Article 1. https://doi.org/10.23860/MGDR-2020-05-02-01

Belmihoub, Mohamed-Cherif (2020), "The Guest of the Editorial Staff," on Radio Alger Channel 3, August 17, 2020, (accessed on August 20, 2020), [available at: https://www.radioalgerie.dz/news/fr/content/197864.html]

Cambefort, Marine (2020), "How the COVID-19 Pandemic is challenging Consumption," Markets, Globalization \& Development Review, 5 (1), Article 2. https://doi.org/10.23860/MGDR-2020-05-01-02

Deaton, Angus (1992), Understanding Consumption, Oxford University Press, Oxford, 240.

De Perthuis, Christian (2020), "How Covid-19 is changing the Outlook for Climate Action, Information and Debates", Climate Economics Chair - University Paris-Dauphine, N ${ }^{\circ} 63$ / April, (accessed on August 18, 2020), [available at: https://www.chaireeconomieduclimat.org/wpcontent/uploads/2020/04/ID-63-EN.pdf]

Dholakia, Nikhilesh and Deniz Atik (2020a), "Rethink Everything 1: Markets, Globalization, Development," Markets, Globalization \& Development Review, 5 (1), Article 1. https://doi.org/10.23860/MGDR-2020-05-01-01 
and

(2020b), "Rethink Everything 2: Markets, Globalization, Development," Markets, Globalization \& Development Review, 5 (1), Article 1. https://doi.org/10.23860/MGDR-2020-05-03-01

Dyen, Margot, Guillaume Le Borgne, and Lucie Sirieix (2020), "How Containment Can Sustainably Transform Our Eating Practices," The Conversation UK, (accessed on August 20, 2020), [available at: https://theconversation.com/comment-leconfinement-peut-durablement-transformer-nos-pratiquesalimentaires-142205]

Ferrell, O.C. and Michael Hartline (2002), Marketing Strategy, $4^{\text {th }}$ ed, Thomson South Western, United States of America.

Flatters, Paul and Michael Willmott (2009), "Understanding the PostRecession Consumer," Harvard Business Review, 7 (8), 106-12.

Gasse, Yvon (2003), "The Influence of the Environment in the Creation of Businesses," Organizations and Territories Review, 12 (2), 49-56. https://doi.org/10.1522/revueot.v12n2.741

Kotler, Philip (2020), "The Consumer in the Age of Coronavirus," Journal of Creating Value, 6 (1), 12-15. https://doi.org/10.1177/2394964320922794

Köksal, Mehmet H. and Engin Özgül (2007), "The Relationship between Marketing Strategies and Performance in Economic Crisis," Marketing Intelligence \& Planning, 25 (4), 326-42. https://doi.org/10.1108/02634500710754574

Langlois, Simon (2002), "New sociological perspectives on consumption," Presses Universities of France, 52 (1), 83-103. https://doi.org/10.3917/anso.021.0083

Lee, R. Nancy and Philip Kotler (2019), Social Marketing: Behavior Change for Social Good $6^{\text {th }}$ ed, SAGE Publications.

Mansoor, Durra and Akram Jalal (2011), "The Global Business Crisis and Consumer Behavior: Kingdom of Bahrain as a Case Study," International Journal of Business and Management, 6 (1), 10415. https://doi.org/10.5539/ijbm.v6n1p104

Marouf-Araibi, Yasmine (2020), "Kamel Rezig: Food Prices Have not Registered a Significant Increase," Interlignes Media, April 26, (accessed on August 25, 2020), [available at: https://www.interlignes.com/kamel-rezig-les-prix-des-produits-Food-Did-NotRecord-a-Significant-Increase] 
Mebtoul, Abderrahmane (2020), "The Decrease Impacts the Unemployment Rate and the Risks of Social Tensions", AlgeriaEco Journal, (accessed on July 27, 2020), [available at: https://www.algerie-eco.com/2020/07/27/mebtoul-ladecroissance-impacte-le-taux-de-chomage-et-le-risque-detensions-sociales/]

Mizukoshi, Kosuke and Yuichiro Hidaka (2020), "We Buy It to Aid: Japan's Aid Consumption during COVID-19," Markets, Globalization \& Development Review, 5 (3), Article 3. https://doi.org/10.23860/MGDR-2020-05-03-03

Moati, Philippe (2020), "Covid 19: What Effects on Consumption?" France 3 Corse ViaStella, Matières à $\mathrm{P}(\mathrm{a} / \mathrm{e})$, June 15, (accessed on June 15, 2020), [available at: https://france3regions.francetvinfo.fr/corse/economie-reponse-qui-consisteprivilegier-solutions-protectionnistes-est-rarement-bonnesolution-1820888.html]

Rochefort, Robert (1997), The Entrepreneurial Consumer: New Ways of Life, Odile Jacob ed, Paris.

Solomon, Michael R. (1996). Consumer Behavior: Buying, Having and Being, 3rd Ed., New Jersey: Prentice Hall.

Tsourgiannis, Lambros, Anastasios Karasavoglou, Christos A. Tsourgiannis, Giannoula Florou, Theodosios Theodosiou, and Stavros Valsamidis (2014), "Factors Affecting Consumers in Greece to Buy during the Economic Crisis Period Food Produced Domestically in Greece," Procedia Economics and Finance, $\quad 9, \quad 439-55 . \quad$ https://doi.org/10.1016/S2212$\underline{5671(14) 00046-X}$ 